\title{
PERFORMANCE ANALYSIS OF TURKISH BANKING SECTOR: CAMELS IMPLEMENTATION
}

\author{
DOI: 10.17261/Pressacademia.2020.1270 \\ PAP- V.11-2020(42)-p.216-218
}

\author{
Caner Koc ${ }^{1}$, Dilek Teker ${ }^{2}$ \\ ${ }^{1}$ Isik University, Institute of Social Science, Istanbul, Turkey. \\ canerkoc5@gmail.com, ORCID: 0000-0002-9976-0565 \\ ${ }^{2}$ Isik University, Faculty of Economics and Administrative Sciences, Department of Management, Istanbul, Turkey. \\ dilek.teker@isikun.edu.tr, ORCID: 0000-0002-3893-4015
}

To cite this document

Koc. C., Teker, D., (2020). Performance analysis of Turkish Banking Sector: CAMELS Implementation. PressAcademia Procedia (PAP), V.11, p.216-218

Permanent link to this document: http://doi.org/10.17261/Pressacademia.2020.1270

Copyright: Published by PressAcademia and limited licensed re-use rights only.

\begin{abstract}
Purpose- These effects lead to many crises in the country, especially the economic crisis, and may result in serious chaos environments. In order not to experience these situations, the banking sector must be under audit and observation. One of the most important a ctions to be taken for this audit and observation is the regular measurement of financial performance analysis of banks. CAMELS analysis is a globally accepted system for this performance analysis. Camels analysis measures banks with components of capital adequacy, asset quality, management quality, profitability, liquidity and sensitivity to market risks.

Methodology- In this study, a total of 16 banks, 2 separate bank groups operating in the Turkish banking sector, 13 of which are private capital banks, 3 of which are Public Banks, were subjected to CAMELS analysis for 16 separate periods taking into account the balance sheets at the end of 2003 and 2018.

Findings- According to the results of the study, among the banks, Türkiye Cumhuriyeti Ziraat Bankası A.Ş., Akbank T.A.Ş. ve Türkiye Gar anti Bankası A.Ş. among the groups, it was observed that the group of Public Banks perform a stronger performance than other banks and groups. Conclusion- The fact that all banks and bank groups operating in the Turkish banking sector have a stronger performance in the coming process will undoubtedly create a more appropriate level of economic prosperity for every structure in the state and individual scale in Turkey's economic sense.
\end{abstract}

Keywords: Banks, financial performance, CAMELS, Turkish banks, Basel standards JEL Codes: M30, M38, Q10

\section{INTRODUCTION}

After funds suppliers and funds demanders Banks are $3^{\text {rd }}$ actors in the financial system. The banking sector accounts for most financial intermediaries. Fund transfer, money supply, economic and financial policies support is some of the main activities. In addition to all its duties within the financial system, it also makes a huge contribution to the employment of the country as a sector. Thus, it has importance and responsibility for all kinds of structures in households, from small to medium-sized enterprises, commercial and corporate companies, to public institutions. All structures will be affected in case of possible crisis that banks will experience. These effects lead to many crises in the country, especially the economic crisis, and may result in serious chaos environments. In order not to experience these situa tions, the banking sector must be under audit and observation. One of the most important actions to be taken for this audit and observation is the regular measurement of financial performance analysis of banks. CAMELS analysis is a globally accepted system for this performance analysis. Camels analysis measures banks with components of capital adequacy, asset quality, management quality, profitability, liquidity and sensitivity to market risks. In this study, a total of 16 banks, 2 separate bank groups oper ating in the Turkish banking sector, 13 of which are private capital banks, 3 of which are Public Banks, were subjected to CAMELS analysis for 16 separate periods taking into account the balance sheets at the end of 2003 and 2018. According to the results of the study, among the banks, Ziraat Bankası A.Ş., Akbank T.A.Ş. ve Türkiye Garanti Bankası A.Ş. among the groups, it was observed that the group of Public Banks had stronger performance than other banks and groups.

\section{LITERATURE REVIEW}

The aim of the study is to examine the factors affecting bank performance in the Turkish banking system. The study examined year -end balance sheet data of selected banks operating in Turkey between 2002 and 2016 . Components were created from financial data a nd those components were examined separately and as a group. Return on equity, capital adequacy, the ratio of total deposits to total assets total loans to total assets ratio of interest income to total assets ratio personnel expenses to total assets ratio of the sum of severance pay and gross domestic product (GDP) year sari exchange, the benchmark interest rate, the rates of reserve requirements, the Consumer Price Index and the exchange rate benefited from the change of showing the variations of the component. Panel data analysis model was used for data analysis. As a result of the study, variables that positively affect the specified components are deposits, total loans, interest income, and net 
non-interest income. The negative variables are capital adequacy ratio, mandatory provision ratios and other operating expenses. Solak (2010) worked on CAMELS performance analysis for the Turkish banking sector before and after the 2001 crisis. The study examined the periods between 1995 and 2008. However, the thesis is based on the 2001 banking crisis. The study showed that the Turkish banking sector suffered a serious wreck during the 2001 crisis. After this wreck, the provision of political stability and the macro-treatment of economic policies strengthened the structures of the banks and positively affected their performance. In addition, CAMELS ratings began to deteriorate in the last data year as a prediction of the 2008 crisis has been interpreted as the reason. Kılıckıran (2010) was examined a ccording to the BCC criteria of 22 different commercial banks according to the results obtained, 15 banks were active in 2007,15 in 2008 and 17 in 2009. According to the CCR criteria, 11 banks were effectively followed in 2007, 15 in 2008 and 14 in 2009. In addition, 10 banks have been observed as effective every 3 years. Hascelik (2019), the study includes measurement and analysis of the financial structures of banks traded in Borsa İstanbul through the CAMELS rating system. The data set was obtained from BAT considering the balance sheets at the end of the period 2008-2018. During the periods studied, the capital adequacy ratios of banks were evaluated at a strong level. However, the average indexation result value of CAMELS components is indicated as 3 . This value has also been described as alarming. Abdullayev (2013), the camels assessment system, generally used for on-site inspection purposes, is one of the important tools of remote surveillance, especially in the United States. This composite performance value, which is used as a means of remote surveillance and on-site supervision to ensure the regular and assured work of banks, is included in this study various analyses made through the CAMELS system created for Turk ey. The data set of the study is provided from the BAT website. In this way, a study using even a "public" data set could provide important clues. The study used 2005 and 2008 as observation years. Aslan (2017), in this study, the activities of the first seven banks in the Turkish banking sector based on their asset size in the 2003-2015 period range were compared with the rate analysis method. Looking at 2015 data, three of the first seven banks surveyed were public-owned banks, three were private-owned banks and one was a foreign-owned bank. The asset size of the first seven banks in the Turkish banking sector was observed to be $74 \%$ of the banking sector in 2015 . In the study, the rate analys is method was preferred because it can show comparisons as an understandable and common technique. The comparison was made with the previous year data and the sector average. As a result of the study, the same public bank ranked first in all of the rates when the banks examined were ranked according to their sector share. In terms of profitability, the Public Bank ranked first in two of the other four. In one of the two ratios, a private-owned bank was ranked first and the other a foreign-owned bank was ranked first. In productivity rates, three out of the four surveyed ranked a private-owned bank in the first place, while one ranked a foreign-owned bank in the first place. As a result of the study, it can be stated that this composite indicator approach, which is based on the camels performance evaluation sy stem and is called the banking sector activity index, will provide important information to all professional market players, investors, risk managers and researchers interested in the performance of both the banking sector and individual banks. In addition, it is thought that it can be used effectively by the auditing authorities in order to determine the problems of banks without growing up and to enable more intensive and frequent supervision.

\section{DATA, METHODOLOGY AND RESULTS}

In this study used 16 separate periods between 2003 and 2018. For 16 separate periods, 16 separate banks were analyzed in different groups. Banks are divided into 3 groups, 1. Group Public Banks, 2. Group private equity Banks, 3. The group is all banks in operation. The raw data set used in the study was taken from the statistical reporting of the Banks Association of Turkey under the name of "Selected Ratios" in certain periods. In this study, used 21 separate ratios that make up each component. These ratios are chosen based on persona l evaluations of authors and subjective evaluations in literature studies. In the weighting of the components, the weighting of the components was done by considering the weighting of the same basis in the literature survey. Accordingly, capital adequacy ratio, asset quality a nd liquidity are weighted at $20 \%$, earnings and market risk sensitivity components are weighted at $15 \%$ and management competence is weighted at $10 \%$. The ratios that make up the components of CAMELS are shown in Table: 7.2. Relationship aspects where the lower ratios positiv ely and negatively affect the components are stated. These relationship aspects are determined by whether the component is affected in a positive or negative direction. For example, equity/total assets increase the capital adequacy ratio. The relationship aspect is positive. Dull receivables / total loans reduce the ratio of assets. The relationship aspect is negative. In the study, CAMELS notes made for the subject banks and groups between 2003 and 2018, the formula and calculation systems used in the creation phase, respectively, are stated below in table 1.

Table 1: Steps for Calculations of the CAMELS

\begin{tabular}{|l|l|l|l|l|l|l|}
\hline Reference Values & Index Value & Deviance Value & $\begin{array}{c}\text { Weighting of the } \\
\text { deviation value of } \\
\text { the ration within the } \\
\text { component }\end{array}$ & $\begin{array}{c}\text { Collection of } \\
\text { weight } \\
\text { deviation } \\
\text { values }\end{array}$ & $\begin{array}{c}\text { Weighting of } \\
\text { total weighted } \\
\text { deviation values } \\
\text { on component } \\
\text { basis }\end{array}$ & CAMELS \\
\hline $\begin{array}{l}\text { The arithmetic mean } \\
\text { of all bank and group } \\
\text { values for the year } \\
\text { analyzed was taken. }\end{array}$ & $\begin{array}{l}\text { The value of } \\
\text { each bank was } \\
\text { multiplied by } \\
100, \text { divided by } \\
\text { that year's } \\
\text { reference value. }\end{array}$ & $\begin{array}{l}\text { It was calculated over } \\
\text { the index value by } 100 \\
\text { basis points depending } \\
\text { on the direction of the } \\
\text { ration's relationship } \\
\text { with the component. }\end{array}$ & $\begin{array}{l}\text { The weight of the } \\
\text { ration is multiplied by } \\
\text { the deviation value. }\end{array}$ & $\begin{array}{l}\text { The ratios that } \\
\text { make up the } \\
\text { components } \\
\text { have been } \\
\text { collected. }\end{array}$ & $\begin{array}{l}\text { The sum of } \\
\text { weighted values is } \\
\text { multiplied by the } \\
\text { weights of the } \\
\text { components. }\end{array}$ & $\begin{array}{l}\text { Calculation of } \\
\text { CAMELS } \\
\text { score }\end{array}$ \\
\hline
\end{tabular}

Table 2 provides analysis scores for the CAMELS values of all banks and groups. The banks and groups that can be interpreted as low performance under the headings for attention are indicated in red, better values which are close to the average in white, values better than the averages in green color groups. The reasons for the low values will be stated in the bank and group-based review in the next section. In the evaluation of CAMELS values on behalf of banks over the years, it would be correct to interpret them by looking at the we ighted values 
of the components that make up the value. It can be misleading to interpret CAMELS directly by looking at the values of the ratios that make up the components. Because the ratios have not yet been weighted to form the value of CAMELS and to show their effect in the value. As a matter of fact, the direct reference of the ratio values for the component-based evaluation we did earlier provided more realistic interpretations.

Table 2: CAMELS Values for Solo Banks and Groups (2003-2018)

\begin{tabular}{|c|c|c|c|c|c|c|c|c|c|c|c|c|c|c|c|c|}
\hline GROUPS & $\mathbf{2 0 0 3}$ & $\mathbf{2 0 0 4}$ & $\mathbf{2 0 0 5}$ & $\mathbf{2 0 0 6}$ & $\mathbf{2 0 0 7}$ & $\mathbf{2 0 0 8}$ & $\mathbf{2 0 0 9}$ & $\mathbf{2 0 1 0}$ & $\mathbf{2 0 1 1}$ & $\mathbf{2 0 1 2}$ & $\mathbf{2 0 1 3}$ & $\mathbf{2 0 1 4}$ & $\mathbf{2 0 1 5}$ & $\mathbf{2 0 1 6}$ & $\mathbf{2 0 1 7}$ & $\mathbf{2 0 1 8}$ \\
\hline Public Capital Banks & 9,0 & 10,7 & 31,8 & 14,1 & 15,7 & 5,4 & 13,4 & 13,4 & 9,0 & 8,5 & 13,0 & 10,1 & 13,6 & 8,0 & 10,3 & $-1,2$ \\
\hline Private Capital Banks & $-1,6$ & $-2,1$ & $-7,1$ & $-3,1$ & $-3,5$ & $-1,2$ & $-3,1$ & $-3,1$ & $-2,1$ & $-1,9$ & $-3,0$ & $-2,3$ & $-3,2$ & $-1,9$ & $-2,4$ & 0,2 \\
\hline Average for the Banks & $\mathbf{3 , 7}$ & $\mathbf{4 , 3}$ & $\mathbf{1 2 , 3}$ & $\mathbf{5 , 5}$ & $\mathbf{6 , 1}$ & $\mathbf{2 , 1}$ & $\mathbf{5 , 1}$ & $\mathbf{5 , 1}$ & $\mathbf{3 , 4}$ & $\mathbf{3 , 3}$ & $\mathbf{5 , 0}$ & $\mathbf{3 , 9}$ & $\mathbf{5 , 2}$ & $\mathbf{3 , 0}$ & $\mathbf{3 , 9}$ & $\mathbf{- 0 , 5}$ \\
\hline
\end{tabular}

\section{CONCLUSION}

The results of the analysis carried out by CAMELS method provide important data about the financial performance of the bank to the bank's Board of directors, especially to those who supply and demand funds, risk managers and many analysts. This data can be used a s an early warning system, helping to create an action plan for potential problems. The performance of banks with an effective supervision and Regulation Authority in the banking sector will also help to interpret the balance sheets with accounting makeup. Furthermore, the performance comparison required for the competitive environment will thus gain continuity. If the competitive environment can be controlled, it creates a positive impact for the markets in the long term. In our study, 16 banks and 2 different bank groups were evaluated in 16 different periods. The assessment is based on the average valuations of the banks and their comparisons to this value on a solo basis. The Public Banks Group is seen as having a strong performance compared to the Private Capital Banks Group. The fact that all banks and bank groups operating in the Turkish banking sector have a stronger performance in the coming process will undoubtedly create a more appropriate level of economic prosperity for every structure in the state and individual scale in Turkey's economic sense.

\section{REFERENCES}

Aksoy, T. (2010). Basel ve İç Kontrol (2. b.). Türmob Yayınları.

Akyel K. (2002). Yeni Basel Antlaşması Basel II. Active Bankacılık ve Finans Dergisi, Sayı 23, 2002: s. 48.

Clasessens S. (2001). Financial Restructuring in Banking and Corporate Sector Crises: What Policies To 129 Purpose?. National Bureau of Economic Research, NBER Working Paper, No.8386, 2001: pn.1-38.

Emek, U. (2002). Devletin Kapasitesi ve İktisadi Kalkınma Sürecindeki İşlevi, Bağımsız Düzenleyici ve Denetleyici Kurumlar ve Türkiye Uygulaması, TÜsiAD Yayınları, No: T/2002-12/349, 2002: s. 58.

Erol M. (2007). BASEL- I ve BASEL- II Uzlaşısı' nın Bankalar Tarafından İşletmelere Verilen Kredilerde Risk Yönetimi Aracı Olarak Kullanılması. Muhasebe ve Finansman Dergisi, (36): 155- 160.

Gilbert R. A., Meyer, A. , Andrew P. and Vaughan, M.(2000). The Role of a CAMEL Downgrade Model in Bank Surveillance, The Federal Reserve Bank of St. Louis Working Paper, No.2000-021A, 2000, pn.1-33.

Karabıyık, L. and Anbar, A. (2010). Küresel Ekonomik Krizin Doğrudan Yabancı Yatırımlar Üzerindeki Etkisi. Muhasebe ve Finansman Dergisi, (46): 44-57.

Sarker, A. A. (2006). CAMELS Rating System in the Context of Islamic Banking: A Proposed 'S' for Shariah.

Sendogdu, A. A. (2010). Basel II Kriterlerinin Dünü Bugünü ve Gelecek İçin Bir Üst Sürümüne Olan İhtiyacın Kaçınılmazlığı. BSAD Bankacılık ve Sigortacılık Araştırmaları Dergisi, 1(2): 4-13.

Van Ray, P. (2012). The Impact of the 1988 Basel Accord on Banks : Capital Ratios and Credit Risk Taking, https://dipot.ulb.ac.be/dspace/ 